\title{
Rursus
}

Russus

Poiétique, réception et réécriture des textes antiques

$6 \mid 2011$

Relire, récrire, prolonger. Adaptations gréco-latines

\section{La langue d'Apollon. Etude linguistique et stylistique des oracles de Delphes}

Résumé de mémoire de littérature grecque (M2) sous la direction de M.

Arnaud Zucker (2009-2010)

The language of Apollo. Linguistic and stylistic study of the oracles of Delphi

\section{Gérard Rainart}

\section{(2) OpenEdition}

Journals

Édition électronique

URL : http://journals.openedition.org/rursus/513

DOI : 10.4000/rursus.513

ISSN : 1951-669X

Éditeur

Université Nice-Sophia Antipolis

Référence électronique

Gérard Rainart, «La langue d'Apollon. Etude linguistique et stylistique des oracles de Delphes », Rursus [En ligne], 6 | 2011, mis en ligne le 28 janvier 2011, consulté le 01 mai 2019. URL : http://

journals.openedition.org/rursus/513; DOI : 10.4000/rursus.513

Ce document a été généré automatiquement le 1 mai 2019.

Rursus 


\section{La langue d'Apollon. Etude linguistique et stylistique des oracles de Delphes}

Résumé de mémoire de littérature grecque (M2) sous la direction de M. Arnaud Zucker (2009-2010)

The language of Apollo. Linguistic and stylistic study of the oracles of Delphi

\section{Gérard Rainart}

1 The Delphic oracles are known mainly through ancient Greek literature. Authors such as Herodotus, Diodorus Siculus, Strabo, Pausanias, Plutarch or Oenomaus of Gadara preserved in Eusebius have quoted them in their works. The oracles are first of all quotations, we mean texts which are not sufficient on their own, away from others texts. In these literary texts, the quotations of Delphic oracles fulfill many functions: they illustrate historical accounts, or they serve as examples to prove moral doctrines in political, religious or social spheres. The oracles are also documents which show the existence and the great power of Apollo's shrine at Delphi.

2 This paper draws on a corpus published by two English researchers Parke and Wormell in 1956. Their catalogue contains 615 texts which in most cases are rhymed, with few exceptions in prose. Parke and Wormell present the oracles with the enquiries and the identity of the enquirers and they always connect them to the literary, epigraphical or lexicographical sources which quote them. We notice that the same oracle can have been quoted in several different works, at different times (between the VIth century B.C. and the IVth century A.D.), either wholly or partly. We observe that the oracles are quoted in several literary works with some morphosyntactic or lexical variants. We cannot conclude that they form a united or specific corpus, and it is impossible to deal with them as we would with texts which make up a whole literary coherence. It is rather a matter of modes of oracular expression, with some syntactic, lexical and stylistic common points between them. 
3 This catalogue has been taken up again by an American researcher J. Fontenrose who, in 1978 , has partly translated the oracles and proposed a new classification based on criteria which justify their historical genuineness or demonstrate their fictitious creation.

4 Academic research from the second part of the XXth century on the Delphic oracles mainly concerns their religious, political or historical status. It describes the history of the Delphic sanctuary. It gives few conclusions on their linguistic, stylistic status: this paper tries to develop this standpoint of the research and takes particular interest in the "poetic" creation" (in the literal and etymological sense).

5 The purpose of this paper is to analyse the linguistic and stylistic aspects and processes of the oracular language. The study is developing in four parts.

6 -The first part shows that linguistically the oracles are exchanges between an enquirer and the god, and form part of the enunciation, because of the recurrence of the verbs

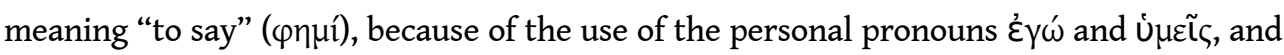
the "deictics" ò $\delta \varepsilon$ and oŨ $\tau o \zeta$, because of the use of the present and future tenses.

7 -The second part analyses the oral marks which researchers have found in the presence of many oracular formulae, in the liking for short utterances as maxims or proverbs, in the versification which often is rough.

8 - The third part is aiming to raise and resolve a paradox: the oracular language is apparently free in the concomitant use of the different Greek dialects in the same text, the creation of neologisms, but demonstrates a strong literary connotation when it takes its inspiration from the Homeric हैं linguistical codes, when it offers examples of meticulous, argumentative constructions.

9 -The fourth part underlines the importance of the images (metaphors), periphrases, puns, plays on syntactic or lexical antitheses, frequent riddles which the god subjects to the clearsightedness of the enquirers.

10 The conclusions of our analyses can be resumed in following points:

11 - The Delphic oracles are considered to be quoted texts which vary less in their enunciation than in their functions.

12 -We can tell that an oracular genre really exists, but the particular genre cannot exist without the others genres and depends on them.

13 -A Delphic oracular genre really exists, because the Delphic shrine was very powerful and very well known in the ancient Greek civilization as a cultural center, because we find in the Greek theatre of the Vth century B.C. imitations of the oracles (pastiche and parody).

14 -The oracles, that we know in their written form, were originally oral texts, and we observe in them many marks of oral language, as marks of improvisation or spontaneity, even if these marks have often been invented by those we call $\pi \rho \circ \varphi \eta ́ \tau \alpha$.

15 -Finally, even if the texts do not belong to a specific and independent work, they present many linguistic and stylistic common marks, which justify the title of this paper: La langue d'Apollon (Apollo's language). 